\title{
ALCOHOL CONSUMPTION AMONG THE WOMEN OF THE NORTHEAST INDIA: THE RELATIONSHIP BETWEEN THE SOCIOECONOMIC STATUS OF THE STATES AND THE PERCENTAGE OF FEMALE POPULATION DRINKING ALCOHOL
}

Salman Hussain, M.A.(economics), Dibrugarh University. Mail id: salmanhussain3006@gmail.com

\section{ABSTRACT}

Keywords:

\section{Introduction and Background:}

In India, Only 1 percent of women drink alcohol, compared with 29 percent of men. Interestingly all north east states has more women drinking alcohol than the national average. The states of Arucnachal Pradesh and Sikkim has the highest figures on this table of women drinking alcohol. The behaviour of alcohol consumption is multidimensional. This paper aims at analysing the internal socioeconomic dynamics of the alcohol consumption the north eastern states of India. Socioeconomic status (SES) indicators (i.e., education, income, and occupation) usually are strong predictors of health behaviours and outcomes and tend to be positively associated with health. Huckle et al. 2010 found that People with a higher socioeconomic status tend to drink more frequently than their counterparts. But low SES groups tend to drink more alcohol in terms of quantity. (Berkman and Kawachi 2000) found that persons with higher levels of social support and community interaction are thought to be healthier due to the access to basic health information, better access to health services, and greater financial support with medical costs. (Conger 1956) explained people consume to deal with stress related to work and other social factors.

Literacy rate is expected to influence the alcohol consuming behaviour in both directions. The more educated a person is, the more he knows about the consequences of the drinking. Alcohol consumption and literacy rate may go in reverse direction to each other. On the other hand, more literacy rate in female shows the liberty enjoyed by the women. Hence alcohol is not considered as a taboo and woman are more open about their usage. A literate society would also mean the better social and community support among the members of the same.

Per capita income is taken as the proxy value of the SES. According to literature the higher the SES the low volume of alcohol consumed. PCI can also be linked to the low level of stress and a higher level of self esteem hence people would be less prone to chronic drinking. However if a person has cultural inclination towards drinking he or she may increase their consumption of the alcohol if given higher income.

Workforce participation of woman may show the equality of status of men and women and hence show the society is more liberal. Unemployment rate however can impact the behaviour of women drinking alcohol in both the directions. Higher employment level would give more income to the women to spend on alcohol but it may also provide for less aspiration led stress to work and hence less probability to go for stress led drinking.

\section{Objective of the study}


The objective of the study is to establish and explain the relationship of the alcohol consumption of the female population of the North-east Indian states with the following variables:
i. Female literacy rate
ii. Per capita income
iii. Workforce participation
iv. Unemployment rate of females

Methodology:

The study is based on secondary data. The impact of the female socio economic indicators on their consumption of alcohol is to be found out by linear regression model.

$$
\begin{gathered}
A L C=\beta(0)+\beta(1) L I T+\beta(2) P C I+\beta(3) W F P \\
+\beta(5) U R+u(i)
\end{gathered}
$$

Where $\mathrm{ALC}=$ percentage of female population(age 15-50) consuming alcohol

$\mathrm{LIT}=$ Female literacy rate

$\mathrm{PCI}=$ per capita income

$\mathrm{WFP}=$ Female workforce participation rate

$\mathrm{UR}=$ Female unemployment rate

Table1: Data of the variables

\begin{tabular}{|l|l|l|l|l|l|}
\hline & $\begin{array}{l}\text { female alcohol } \\
\text { consumption(1) }\end{array}$ & Female literacy(2) & $\begin{array}{l}\text { PCI(3)(year } \\
2013-14)\end{array}$ & $\begin{array}{l}\text { Forkforce } \\
\text { participation(4) }\end{array}$ & $\begin{array}{l}\text { unemployment } \\
\text { rate(5) }\end{array}$ \\
\hline assam & 6.9 & 66.27 & 44263 & 22.46 & 8.4 \\
\hline arunachal & 26.3 & 57.7 & 85468 & 35.44 & 2.9 \\
\hline manipur & 6.1 & 70.26 & 41573 & 38.56 & 2.7 \\
\hline meghalya & 2.1 & 72.89 & 61548 & 32.67 & 6.9 \\
\hline tripura & 4.8 & 82.73 & 76120 & 23.67 & 16.8 \\
\hline mizoram & 4.9 & 89.27 & 69705 & 36.16 & 2.3 \\
\hline nagaland & 3.3 & 76.11 & 77529 & 44.74 & 6.1 \\
\hline Sikkim & 23 & 75.61 & 176491 & 39.57 & 13.2 \\
\hline
\end{tabular}

Source:

1. National Family and health survey data 4

2. Census 2011 data

3. trak.in data

4. Women \& Men in India -2017, Ministry of Statistics and Programme Implementation

Results:

Table2: Regression results

\begin{tabular}{|l|l|l|l|}
\hline variables & Coefficients & Standard errors & probability \\
\hline intercept & 49.6822 & \multicolumn{1}{|c|}{16.2743} & 0.055 \\
\hline LIT & -0.46431 & 0.19946 & 0.102 \\
\hline PCI & $-0.2470 \mathrm{e}-3$ & $0.6794 \mathrm{e}-4$ & 0.036 \\
\hline WFP & -0.52433 & 0.38062 & 0.262 \\
\hline UR & -0.99030 & 0.60515 & 0.200 \\
\hline
\end{tabular}

Findings and Analysis:

The coefficient of the variable LIT (literacy rate of woman) is found to be negatively related to the 
proportion of the woman consuming alcohol. But the result is not statistically significant. The conclusion we can derive is that with higher woman getting educated they tend to involve in consuming less alcohol as a whole. This shows that educated woman knows more of the consequences of the alcohol consumption and hence stays away from it.

The coefficient of the variable PCI is found to be positive and significant. Hence it shows that the higher the socioeconomic status of the particular state the lower the chance of the woman consuming alcohol. As the states develop economically the chances of the women involving in the consumption of alcohol is less.

The coefficients of the workforce participation rate and Unemployment rate are found to be negative but not significant. Hence we can conclude that the general trend is that the chance of the woman consuming alcohol goes down as more women are willing to participate in the workforce and gets more employment opportunities.

\section{Conclusion:}

The analysis shows the poorer the state is higher chance of women drinking alcohol. The behaviour becomes less prevalent as the state gets into a higher standard of living and women get more opportunities of employment and education. Hence policy design must be such that the development drives the women out of the consumption of alcohol.

\section{References:}

[1] Huckle, T., You, R. Q., \& Casswell, S. (2010). Socio-economic status predicts drinking patterns but not alcohol-related consequences independently. Addiction (Abingdon, England), 105(7), 1192-1202. https://doi.org/10.1111/j.1360$\underline{0443.2010 .02931 . x}$

[2] Kawachi, I., \& Berkman, L. F. (2001). Social ties and mental health. Journal of urban health : bulletin of the New York
Academy of Medicine, 78(3), 458-467. https://doi.org/10.1093/jurban/78.3.458

[3] CONGER, J. Reinforcement theory and the dynamics of alcoholism. Quarterly Journal of Studies on Alcohol 17:296-305, 1956.

[4] India, Ministry of Health and Family Welfare. (2015-16). National Family Health Survey(NHFS-4).

(n.d.). Retrieved December 20, 2020, from https://trak.in/2012/average-per-capitaincome-indian-states/

[5] India, Ministry of Statistics and Programme Implementation. (2016-17). Women and men in India. 